\title{
Türkiye'nin fındık üretiminde önde gelen illerin 2019-2025 yılları arasındaki fındık üretimlerinin ARIMA modeliyle tahmin edilmesi
}

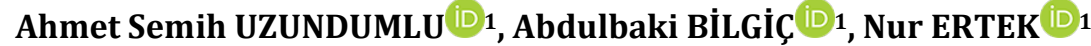

${ }^{1}$ Atatürk Üniversitesi, Ziraat Fakültesi, Tarım Ekonomisi Bölümü, 25240 Erzurum

Alınış tarihi: 13 Temmuz 2019, Kabul tarihi: 13 Aralık 2019

Sorumlu yazar: Nur ERTEK, e-posta: nertek@atauni.edu.tr

\section{Öz}

Son yıllarda fındık üretimi 16 ilde sınırlandırılmış olmakla birlikte birinci ve ikinci sınıf ile eğimi \%6'nın altında olan arazilerde yeni fındık bahçeleri oluşturulması kanunen yasaklanmıştır. Bu özellikleri içinde barındıran illerde findık üretiminin yaygınlaştırılması arzulanmaktadır. $\mathrm{Bu}$ çalışmanın amacı Türkiye findık üretiminde önde gelen 10 ilin gelecek 7 yll için üretimlerinde meydana gelecek değişimleri tahmin etmektir. Çalışmada TÜİK 19912018 verileri dikkate alınarak, geleceğe yönelik tahminlerin elde edilmesinde ARIMA modelleri kullanılmıştır. AIC, BIC, SSE, MSE ve MAPE gibi kriterler dikkate alınarak en uygun ARIMA modeli belirlenmiştir. Türkiye'de son 28 yılın ortalamasına göre en fazla findık üretimi yapan iller \%27.82 ile Ordu, \%16.28 ile Sakarya, \%14.77 ile Giresun, \%11.52 ile Samsun, \%8.75 ile Trabzon, \%8.68 ile Düzce, \%3.69 ile Zonguldak, \%1.66 ile Kocaeli, $\% 1.15$ Artvin ve $\% 0.55$ ile Bartın'dır. Söz konusu on il Türkiye findı üretiminin \%94.87'sini oluşturmaktadır. Çalışma sonuçlarına göre 20192025 yılları arasında Türkiye'de ortalama yıllık 589 bin ton findık üretilecek ve bu 10 il Türkiye fındık üretiminin \%97.89'unu oluşturacaktır. Verim ve fiyat dikkate alındığında bu illerde genel itibariyle verim ve kalite artışı sağlanmaktadır. Bu amaçla bazı illerdeki verim ve fiyat düşüşlerinin önüne geçmek için Fındık Enstitüsü tarafından bu illere yönelik geliştirilecek verim ve katma değeri yüksek fındık çeşitlerine ihtiyaç duyulmaktadır. Ayrıca yaşlanmış bahçelerin bu çeşitler ile gençleştirilmesi verim ve kalite artışını sağlayacaktır.

Anahtar kelimeler: ARIMA, fındık, üretim, tahmin, Türkiye
Prediction of hazelnut production quantity with the ARIMA model of Turkey's provinces leading hazelnut production in the last seven years

\section{Abstract}

Although the production of hazelnuts has been limited in 16 provinces in recent years, the establishment of new hazelnut orchards is prohibited by law when first, second class and slopes in the land of below 6 percent. It is desirable to expand hazelnut production in the provinces that contain these features. The aim of this study is to forecast changes of leading ten provinces in Turkey's hazelnut production in the future seven years. In the study, ARIMA models were used to obtain the forecasts for the future by taking into account the data of TURKSTAT 1991-2018. Considering the criteria such as AIC, BIC, SSE, MSE and MAPE the most appropriate ARIMA model has been determined. According to the 28-year average, the provinces with the highest production were Ordu, Sakarya, Giresun, Samsun,Trabzon, Düzce, Zonguldak, Kocaeli, Artvin and Bartın, which their percentage were $27.82,16.28,14.77,11.52$, 8.75, $8.68,3.69,1.66,1.15$ and 0.55 , respectively. These ten provinces constitute 94.87 percent of Turkey's hazelnut production. According to the average of the years 2019-2025, these provinces will produce annually average 589 thousand tons hazelnuts and will be provide $97.89 \%$ of Turkey's hazelnut production. When yield and price are taken into consideration, yield and quality increase is generally provided in these provinces. However, there are needed to be developed hazelnut varieties by the Hazelnut Institute order to prevent yield and price decreases in some provinces. In addition, both yield 
and quality will be increased with rejuvenated of aging gardens with these varieties.

Key words: ARIMA, hazelnut, produce, forecast, Turkey

\section{Giriş}

Dünya genelinde üretimi yapılan sert kabuklu meyveler 8 tane olup, yüzde olarak dağılım dikkate alındığında kaju \%25.49'luk payı ile ilk sırada yer almaktadır. Diğer sert kabuklu meyveler ceviz (\%24.58), kestane (\%14.94), badem (\%14.38), antepfistığı (\%7.16), findık (\%6.46), yer fistığı $(\% 6.45)$ ve çamfistığı $(\% 0.54)$ olarak sıralanmaktadır. Aynı durum Türkiye açısından incelendiğinde Türkiye'de sert kabuklu meyvelerden kaju yetiştirilememekte ve çam fistığı ise üretimi yeni olduğu için sert kabuklular içeresindeki payı çok düşük olmaktadır.

Türkiye'de sert kabuklu meyve yetiştiriciliğinde fındık \%61.32 ile ilk sırada, \%18.77 ile ceviz 2. sırada, \%8.04 ile badem 3. sırada, \%6.97 ile antepfıstığı 4. sırada, \%5.62 ile kestane 5 . sırada ve $\% 0.28$ ile yer fistığı 6. sırada yer almaktadır (FAOSTAT, 2019). Sert kabuklu meyveler içerisinde önemli bir paya sahip olan fındık, özellikle Akdeniz iklim kuşağındaki ülkelerin dağlık veya tepelik bölgelerinin dik yamaçlarında yetiştirilmektedir (Tombesi, 2005). Fındık Betulaceae (huşgiller) familyasından Corylus cinsine ait on türü olup dünyada çok az ülkede üretimi yapılmaktadır (Yaltirik ve Efe, 2000; Fideghelli ve ark., 2009). Fındık, 2017 yılı itibari ile dünyada Türkiye'nin de dâhil olduğu 30 ülkede üretimi yapılan önemli meyvelerden biridir (FAOSTAT, 2019). Türkiye'de 1991-2018 yılları itibari ile yıllık ortalama 520.000 ton findık üretilmektedir (TÜİK, 2019). Bir önceki dönemde arz fazlası olan findık depolarda bekletilmekte ve bir sonraki dönem arz ve talep oluşumunda dikkate alınmaktadır. Arz edilen fındığın yaklaşık olarak \%6-15'i arz fazlası olmakta bu nedenden dolayı bir sonraki yıl depolarda saklanarak devir stokunu oluşturmaktadır. Atsan ve Karapınar (2019)'a göre Türkiye'de ülke içinde talep edilen findık, toplam talebin 2011-2018 yılları dikkate alındığında \%12-16'llk bir kısmını oluşturduğu tespit edilmiştir. FAO 1961-2017 yılları ortalamasına göre ise dünyada üretilen findığın $\% 65$ 'i Türkiye tarafından sağlanırken, Türkiye dışında findık üretiminde İtalya \%17.8, Gürcistan \%3.7, ABD \%3.6 ve Azerbaycan \%3.5'lik paya sahiptir. Ayrıca son yıllarda İtalya'nın dünya fındık üretimindeki payı azalırken Gürcistan ve Azerbaycan'ın payı giderek artmaktadır (FAOSTAT, 2019). Fındık işlenmeden çerezlik olarak tüketildiği gibi işlenerek çikolata veya yağ olarak ta tüketilebilmektedir (Tombesi, 2005). Dünya fındık üretiminin \%80'i çikolata sektöründe, \%13-15'i unlu mamuller, bisküvi, tatlı ve dondurma sektöründe ve \%3-5'i de pazarlamada çerez olarak kullanılmaktadır (Kilic ve Alkan, 2006; ZMO, 2018). Türkiye'de fındığın kullanım alanına bakıldığında \%70'i çikolata sanayinde, $\% 20$ 'si pasta-tatlı yapımında ve $\% 10$ 'u da çerezlik olarak satılmaktadır (Anil ve ark., 2018; Bars ve ark., 2018). Türkiye'de fındık, yetiştirildiği bölgelerdeki tarım işletmeleri için önemli ve hatta birçok tarım işletmesi için tek geçim kaynağı olmasının yanı sıra, işleme ve pazarlama aşamalarında büyük bir nüfus kitlesi için de istihdam imkânı sağlamaktadır (Eryılmaz ve Kılıç, 2019).

Türkiye'de yaklaşı 700.000 ha alanda findık üretimi yapılmakla beraber 440.000 ailenin geçiminde önemli bir paya sahiptir. Özellikle Karadeniz Bölgesi'ndeki başka ürünün üretiminin mümkün olmadığı engebeli tarımsal arazilerin büyük bölümünde findık üretimi yapılmaktadır (Atsan ve Karapınar, 2019). Fındık, Türkiye'nin dış ticaretinde çok önem verdiği ürünlerden birisidir ITC (2019) verilerine göre Türkiye 2018 yllında 161.332 ton kabuklu ve kabuksuz fındık ihraç etmiş ve 22.55 milyon \$ döviz kazanmıştır. Ayrıca dünya fındık üretimi ve ihracatının büyük bir çoğunluğunu sağlayan ülke olması nedeniyle Türkiye, dünya fındık fiyatının belirlenmesinde avantajlı bir ülke konumundadır. Türkiye'de bol ürün yıllarında dünya fındık fiyatı düşerken, kıt ürün yıllarında ise fiyatlar aşırı yükselmektedir. Fındığın depolanabilir ürün olması, onun bir artısı olarak görülmekle birlikte Türkiye'nin yeni pazarlara girmesi ve onun katma değeri yüksek ürünlere dönüștürmesi ile daha fazla döviz girişi sağlanabilmektedir (Uzundumlu ve Kurtoglu, 2018). Ancak üretimin çok fazla olduğu dönemlerde depolama masrafları Türkiye'ye önemli maddi kayıp oluşturmaktadır.

Türkiye'de 1991-1997 döneminde 29-35 ilde, 19982004 döneminde 31-32 ilde, 2005-2011 döneminde 32-39 ilde ve 2012-2018 döneminde 28-32 ilde fındık yetiştirilmektedir. Bazı yıllarda 39 ilde fındık üretimi yapılmasına karşın Ordu, Giresun, Samsun, Sakarya, Düzce, Trabzon, Zonguldak, Artvin, Kocaeli ve Bartın illerindeki üretim toplam üretimin $\% 95$ 'ini oluşturmaktadır (TÜIK, 2019). Findık üretimine 
makro açıdan bakıldığında daha önceki yıllarda findık üreticisi olmayan Gürcistan ve Azerbaycan'ın üretime başlayarak gelecekte önemli bir paya sahip olması beklenmektedir. Mikro açıdan bakıldı̆̆ında ise Türkiye'nin önde gelen illeri için benzer bir durumun gelecekteki 7 yll içinde gerçekleşme ihtimali çalışmada önem arz etmektedir.

Bu çalışma, Türkiye fındık üretiminde önde gelen ve toplam findık üretiminin \%95'ini oluşturan 10 il ve diğer iller toplamının 2019 ile 2025 yılları arasındaki 7 yıllık dönem için findık üretim tahminlerini elde etmek amacıyla yapılmıștır.

\section{Materyal ve Yöntem}

Materyal

Çalışmada kullanılan ikincil veri kaynakları olarak TÜİK olmak üzere, FAO ve ITC veri kaynaklarından yararlanılmıştır. Bunun dışında birçok ulusal ve uluslararası makale, bildiri, rapor, yüksek lisans ve doktora çalışmasından da faydalanılmıştır.

\section{Yöntem}

Bu çalışmada son 7 yıla (2019-2025 yıllarına) ait Türkiye'de fındık üretiminde önde gelen on ilin findık üretimlerinin tahminini belirlemede ARIMA modeller kullanılmıștır. Çalışmada Türkiye'de fındık üretiminde önde gelen 8 ilin 1991-2018 yıllarına ait 28 yllık, Düzce ilinin 19 ve Bartın ilinin 27 yıllık verileri AIC, BIC, SSE, MSE ve MPE gibi kriterler SAS istatistik programında analiz edilerek her ilin en iyi tahmini veren ARIMA modelleri belirlenmiștir.

\section{ARIMA modelleri}

Zaman serisinde belirli bir dönem içerisinde gözlemlenen veriler bir araya getirilmekte ve bu serilerle birtakım analizler yapılmaktadır. $\mathrm{Bu}$ analizlerden bazıları bu verileri kullanarak geleceğe yönelik tahminler geliştirilmektedir. Bu tahminleri yapan analizlerden birisi de ARIMA'dır. Bu modelin geçmişteki verilere yönelik bir formülasyon oluşturmaması diğer tahmin etme modellerine göre farklılığını ortaya koymaktadır. Bu model durağan ve durağan olmayan zaman serilerini analiz etme becerisine sahip olan modellerden biridir. Bu modeli oluşturma da Box-Jenkins prosedürü geçerlidir (Nath ve ark., 2019). Box-Jenkins metodolojisinin yaklaşımı şu aşamaları içermektedir: (1) Model belirleme, (2) Parametre tahmini (3) Teşhis ve denetim (model yeterli mi?) ve (4) Modelin kullanımı ve tahminin yapılması (Kohvakka, 2017). ARIMA modeli 1970'li yıllarda Box ve Jenkins tarafından geliştirilmiş olup, tahminleri tek bir değişkeni dikkate alarak yapmaktadır. Bu modeller 3'e ayrılmaktadır (Box ve ark., 2016).

1- Durağan doğrusal stokastik modeller (ARMA),

2- Durağan olmayan doğrusal stokastik modeller (ARIMA) ve

3- Mevsimsel modeller (SARMA)'dır.

Mevsime bağlı olmayan Box-Jenkins modelleri veriler durağan olduğunda ( $\mathrm{d}=0$ olacağından) model $\operatorname{ARMA}(p, q)$ şeklinde gösterilmekte ve eğer veriler durağan olmayan verilere uygulandığında ise model $\operatorname{ARIMA}(\mathrm{p}, \mathrm{d}, \mathrm{q})$ olarak yazılmaktadır. ARIMA modellerinde $\mathrm{p}$ otoregresyon modelinin (AR) derecesini, d fark alma sayısını ve $\mathrm{q}$ ise hareketli ortalama modelinin (MA) derecesini göstermektedir (Yıldırım ve Alkan, 2018). ARIMA modellemesini yapmadan önce, bazı varsayımların yapılması gerekmektedir. Bu varsayımlar 4 tanedir (Hasmida, 2009; Kurtoğlu, 2018):

1. Veriler durağan olmalı, durağan değilse verilerin bir veya ikinci yıla göre gecikmesi alınmalı,

2. Veriler normal dağılım göstermeli,

3. Verilerde hiçbir aykırı durum olmamalı ve

4. Verilerde eksiklik olmamalıdır.

ARIMA modeller verinin durağan olup olmadığını ve geçmiş dönemdeki verilerden etkilenip etkilenmediğini ortaya koymaktadır. Bunu belirlemek için regresyon denklemi oluşturan birçok test mevcut olup bu testlerden birisi de DickeyFuller testidir. Bu test verilerde birim kök olduğu yani serinin durağan olmadığ 1 durumlarda verilerin birinci, ikinci veya üçüncü dereceden farkı alınarak durağanlaştırılmaktadır (Şahin, 2016). Verilerin durağan olup olmaması, ortalaması ve beklenen değeri sıfır olan sabit varyanslı "Beyaz Gürültülü (White Noise)" zaman serisi durağan bir seri iken, "Rastgele Yürüyüş (Random Walk)" serisi, varyansı sabit olmayan, sabit ortalama etrafında dağlmayan durağan olmayan bir seridir (İpek, 2019). Verileri analize uygun hale getirmek için excele aktarılan zaman serileri verilerinin sağına 4 sütun açlarak $t$, $t_{1}, t_{2}$ ve $t_{3}$ olmak üzere $t^{\prime} y e$ göre üç ylllık gecikme değerleri yazılmaktadır. Örneğin 25 yıllık veriler temel alınıyorsa t sütununda, 1'den 25'e kadar değerler hiyerarşik olarak kaydedilmekte ve $t_{2}$ sütununda ilk iki satır boş bırakılıp 1'den 23'e kadar sayılar sıralanmaktadır. Böylece SAS vb. paket programlarda bu veriler analize tabi tutulmaktadır. En iyi modeli belirlemek için değişik kriterler kullanılmaktadır. Bunlardan en çok kullanılanları Akaike Information Criteria (AIC) ve Bayesian 


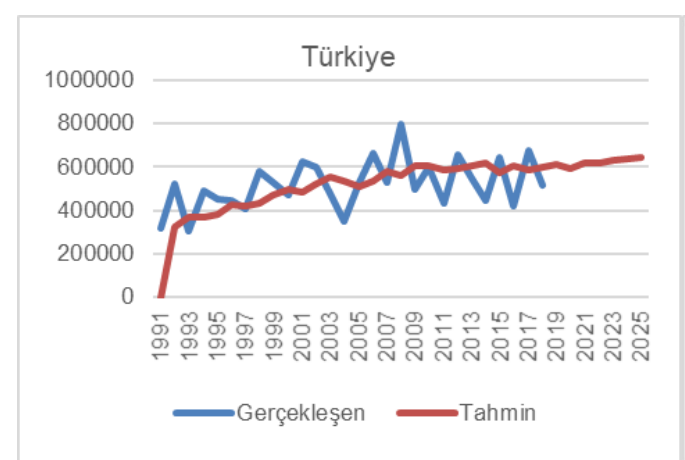

a)

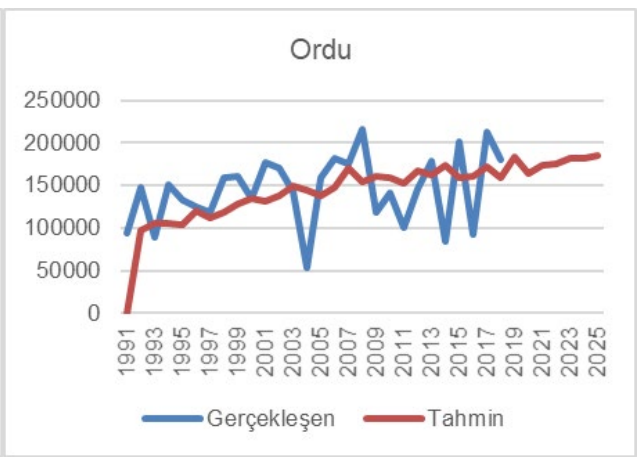

b)

Şekil 1. Türkiye ve Ordu ilinin gerçekleșen ve tahmin edilen fındık rekolteleri (ton)

Information Criteria (BIC)'tir (SAS, 2014). SAS programinda SCAN ve ESACF ile belirlenen BIC değerlerini elde eden $\mathrm{p}$ ve $\mathrm{q}$ değerleri tekrardan analize koşularak en küçük BIC ve AIC değerlerini destekleyen en küçük SBC, SSE, MSE, MAE, MAPE, RMSE ve DW sonuçlarına göre en uygun ARIMA modeller tespit edilmektedir.

\section{Araştırma Bulguları ve Tartışma}

\section{Fındık üretiminde önde gelen illerin arıma modeline göre 1991-2025 yıllarındaki gerçekleşen ve tahmin edilen findık rekolteleri}

Türkiye'de giderek artan bilinçsizce yapılan tarım nedeniyle 2014 yılı bakanlar kurulu kararı ile 16 il ve bunlara bağlı 123 ilçede findık dikimi yapılması karara bağlanmıștır (ZMO, 2018). Bu iller içerisinde yer alan ilk 10 ilin önceki dönemlerdeki üretimleri temel alınarak sonraki 7 yıldaki tahmini üretimleri Şekil 1-6'da verilmiştir.

Şekil 1'de Türkiye ve Türkiye'nin en fazla üretim yapan ili olan Ordu'da gerçekleşen ve tahmin edilen fındık üretimleri verilmiştir. Türkiye ve Ordu için

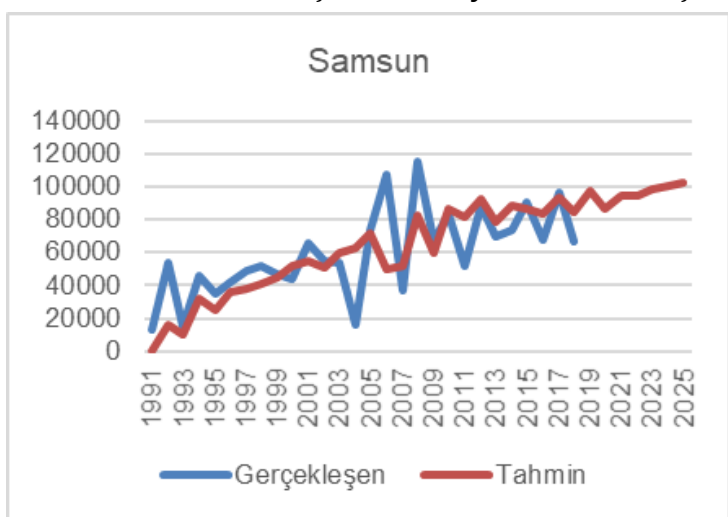

a) oluşturulan gerçekleşen ve tahmini değerleri benzerlik göstermektedir. Çünkü Ordu ili Türkiye üretiminin yaklaşık \%30' unu karşılamaktadır. Yıllar itibari ile Türkiye'nin üretimi yaklaşık olarak 350.000-800.000 ton arasında değișirken, Ordu ilinin üretimi ise 50.000 ve 220.000 ton arasında olmaktadır. 1991-2025 yılları dikkate alındığında Türkiye ve Ordu ili için tahmin edilen üretim düzeyleri sırası ile 350.000-620.000 ton ve 100.000180.000 ton arasında tahmin edilmektedir. 2003 yılında en düşük üretim miktarı hem Türkiye hem de Ordu için gerçekleşmiş olup, bu dönemde findıkta don olayının olduğu belirgin olarak görülmektedir. 2018-2025 yıllarında Türkiye'nin fındık üretiminin 600.000 tonun üzerinde olması beklenmekte aynı şekilde Ordu ilinde 150.000 tonun üzerinde bir üretim beklenmektedir. 2014 yılı Bakanlar Kurulu kararında bazı iller ve ilçelerinde fındık üretiminde sınırlandırma getirirken, Ordu ili ve tüm ilçeleri bu sınırlamalar dâhilinde değildir. Bu da Ordu ilinin son 7 yılda da findık üretiminde ilk sırada olacağının bir kanıtı niteliğindedir (ZMO, 2018).

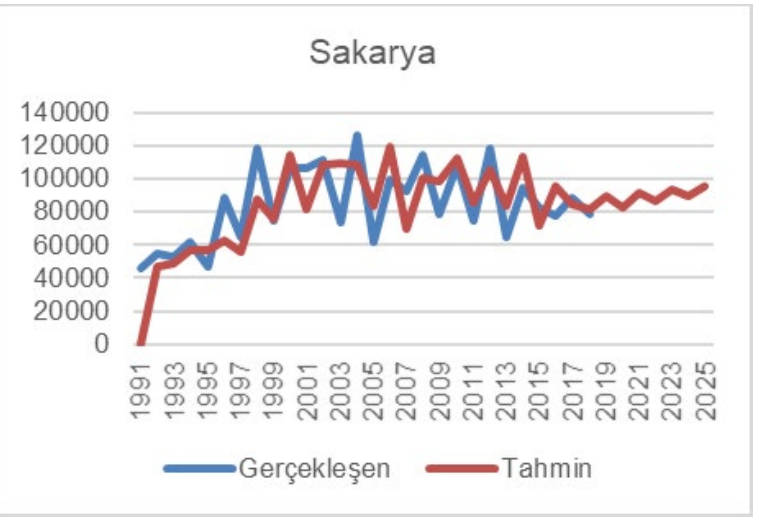

b)

Şekil 2. Samsun ve Sakarya illerinin gerçekleșen ve tahmin edilen findık rekolteleri (ton)

Fındık üretiminde iki ve üçüncü sırada yer alan iller Samsun ve Sakarya olup, bu illerden 50.000-120.000 ton yllık ürün elde edilmektedir. Samsun, Ordu ilinde olduğu gibi 2003 yılındaki dolu nedeniyle 
findık üretiminde büyük düşüşler yaşamıștır. Fındık üretiminde bu iki ilde beklenen ve gerçekleşen değerler arasında çok fazla bir farklılık olmadığ görülmektedir. Ayrıca bu iki ilin üretim düzeyinin son 7 yılda 100.000 ton civarında olması beklenmektedir. 1983 yılında çıkarılan 2844 sayılı fındık üretim alanlarının planlanması hakkındaki kanunda amaç findığın en uygun alanlarda üretiminin yapılabilmesi ve talepteki gelişmelere göre üretim planlaması yapmak içindir. $\mathrm{Bu}$ amaçla 2014 yılı bakanlar kurulu kararı ile Samsun ilinin,
Çarşamba, Terme, Ayvacık, Salıpazarı, Ondokuzmayıs, Tekkeköy, Alaçam, Yakakent, İlkadım, Bafra, Asarcık, Canik, Atakum ilçelerinde ve Sakarya ilinin Kocaali, Karasu, Akyazı, Hendek, Ferizli, Karapürçek, Kaynarca, Adapazarı, Arifiye, Erenler, Geyve, Pamukova, Sapanca, Serdivan, Söğütlü ve Taraklı ilçelerinde findık üretimine izin verilmektedir (ZMO, 2018).

Şekil 3'te Giresun ve Düzce illerinin gerçekleşen ve tahmini fındık üretimleri verilmiștir.

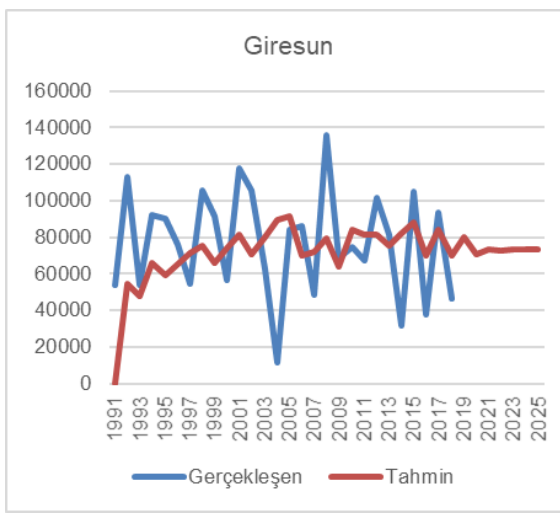

a)

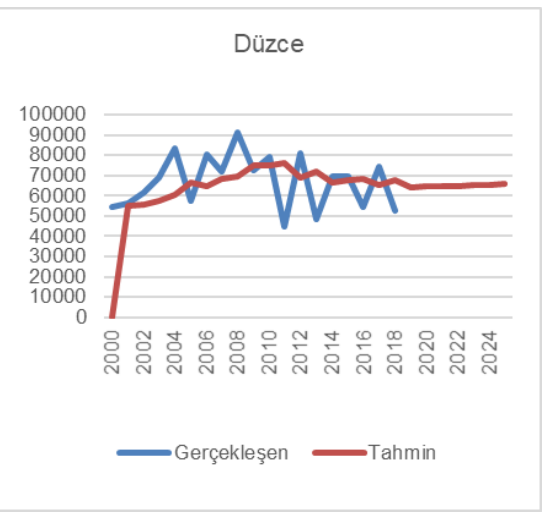

b)

Şekil 3. Giresun ve Düzce illerinin gerçekleşen ve tahmin edilen fındık rekolteleri (ton)

Düzce ilinde findık üretimi 2000 yılından itibaren başlamış olup 60-70 bin ton yıllık rekolteye sahiptir. Giresun ili yıllık ortalama 75-80 bin tonluk fındık üretimine sahip olup, yıllar itibari ile çok fazla bir dalgalanma göstermektedir. Yıllar itibari ile Giresun ilinin üretimi yaklaşık olarak 20.000-140.000 ton arasında değişirken, Düzce ilinin üretimi ise 40.000 ve 90.000 ton arasında olmaktadır. 1991-2025 yılları dikkate alındığında Giresun ilinin tahmin edilen üretim düzeyleri 55.000-90.000 ton arasında değișmekte iken, 2000-2025 ylları dikkate alındığında Düzce ilinin üretimi 57.000-77.000 ton arasinda tahmin edilmektedir. ZMO (2018)'de belirtildiği üzere fındık üretim alanlarının planlanması dikkate alındığında Giresun ilinde Merkez, Bulancak, Keşap, Tirebolu, Görele, Eynesil, Espiye, Dereli, Çanakçı, Güce, Doğankent, Yağlıdere, Piraziz ilçelerinde ve Düzce ilinde Merkez, Akçakoca, Cumayeri, Gölyaka, Çilimli, Gümüşova, Yığllca ve Kaynaşlı ilçelerinde fındık üretimine izin verilmektedir.

Şekil 4'te Trabzon ve Zonguldak illerinin gerçekleşen ve tahmini fındık üretimleri verilmiştir.

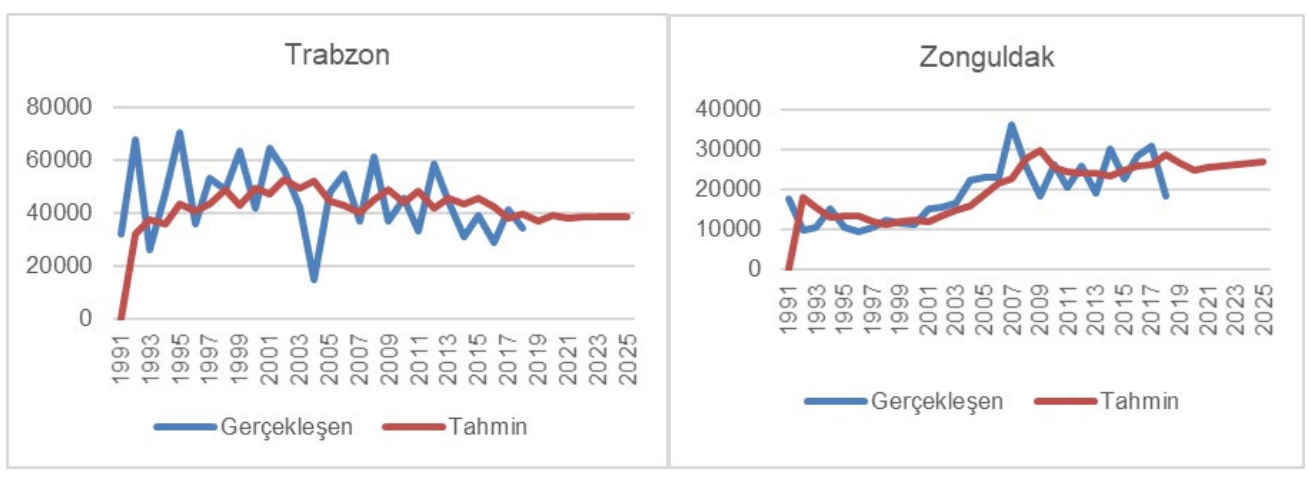

a)

Şekil 4. Trabzon ve Zonguldak illerinin gerçekleşen ve tahmin edilen fındık rekolteleri 
Trabzon ili 40-50 bin ton ve Zonguldak ili 20-25 bin tonluk yıllık ortalama findık üretimine sahip olup, yıllar itibari ile Trabzon ilinin üretimi yaklaşık olarak 18.000-65.000 ton arasında değişirken, Zonguldak ilinin üretimi ise 10.000-37.000 ton arasında olmaktadır. 1991-2025 yılları dikkate alındığında Trabzon ve Zonguldak ilerinin tahmin edilen üretim düzeyleri sırası ile 37.000-50.000 ton ve 10.000-
30.000 ton arasında değişmektedir. ZMO (2018)'de belirtildiği üzere fındık üretim alanlarının planlanması dikkate alındığında Trabzon ve Zonguldak ilinin tüm ilçelerinde findık dikimi yapılabilmektedir.

Şekil 5 'te Artvin ve Kocaeli illerinin gerçekleșen ve tahmini findık üretimleri verilmiştir.

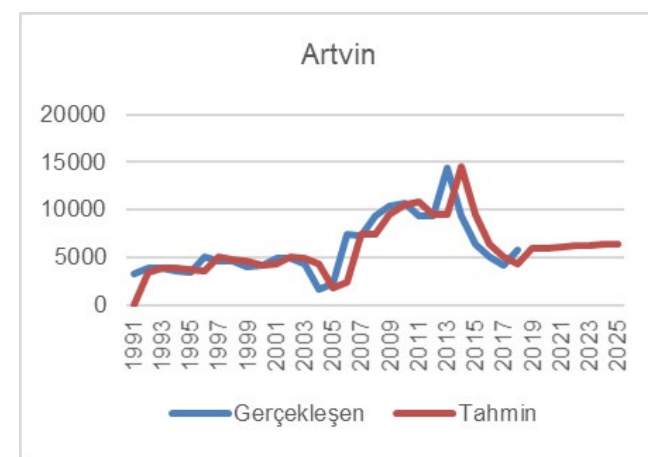

a)

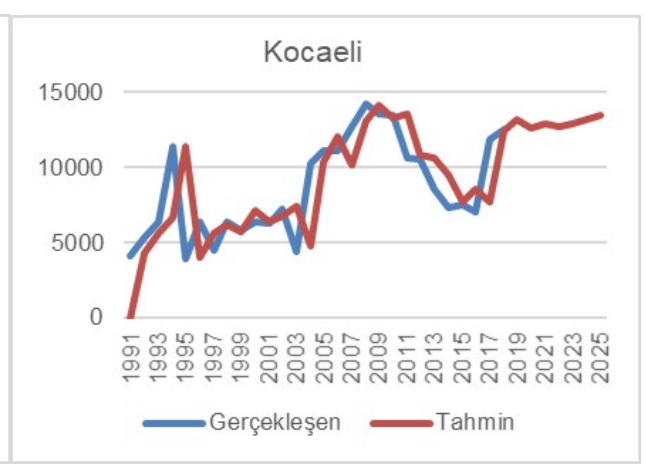

b)

Şekil 5. Artvin ve Kocaeli illerinin gerçekleşen ve tahmin edilen fındık rekolteleri

Artvin ili 7-8 bin ton ve Kocaeli ili 9-10 bin tonluk yıllık ortalama fındık üretimine sahip olup, yıllar itibari ile Artvin ilinin üretimi yaklaşık olarak 4.00015.000 ton arasında değişirken, Kocaeli ilinin üretimi ise 4.000-14.000 ton arasında olmaktadır. 19912025 yılları dikkate alındığında Artvin ve Kocaeli ilerinin tahmin edilen üretim düzeyleri sırası ile 4.000-15.000 ton ve 4.000-14.000 ton arasinda değişmektedir. ZMO (2018)'de belirtildiği üzere fındık üretim alanlarının planlanması dikkate alındığında Artvin ilinin Arhavi, Borçka, Hopa, Murgul ve Kocaeli ilinin Kandıra ilçesinde fındık dikimi için izin verilmektedir. Şekil 6'da Bartın ve önde gelen illerin dışındaki diğer illerin gerçekleşen ve tahmini fındık üretimleri verilmiștir.

Bartın ili ile Türkiye'nin diğer illeri 3-4 bin tonluk yıllık ortalama findık üretimine sahip olup, yıllar itibari ile Bartın ilinin üretimi giderek artarken diğer illerin payı giderek düşmüştür. Bartın ilinin üretimi 1992'de bașlamıș olup, Bartın ve diğer illerin üretimi 1.000-7.000 ton arasında olmaktadır. 1991-2025 yılları dikkate alındığında Bartın ilinin tahmin edilen üretim düzeyi 1.000-7.000 ton ve diğer illerin 5007.000 ton arasında değişmektedir. Fındık üretim alanlarının planlanması dikkate alındığında Bartın ilinin tüm ilçelerinde ve Diğer illerin bazı ilçelerinde fındık dikimi için izin verilmektedir (ZMO, 2018).

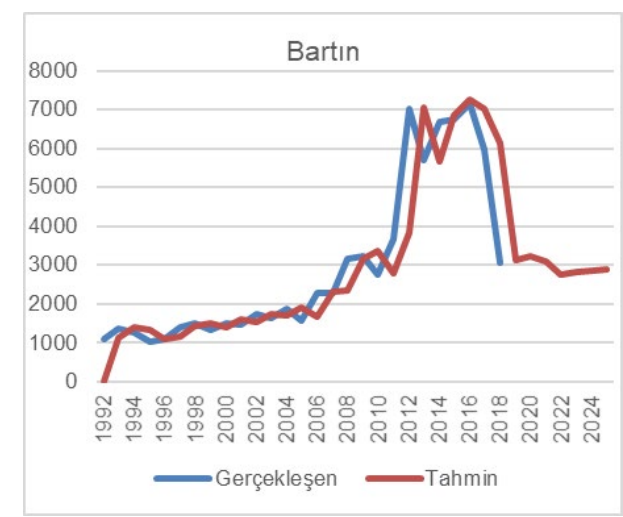

a)

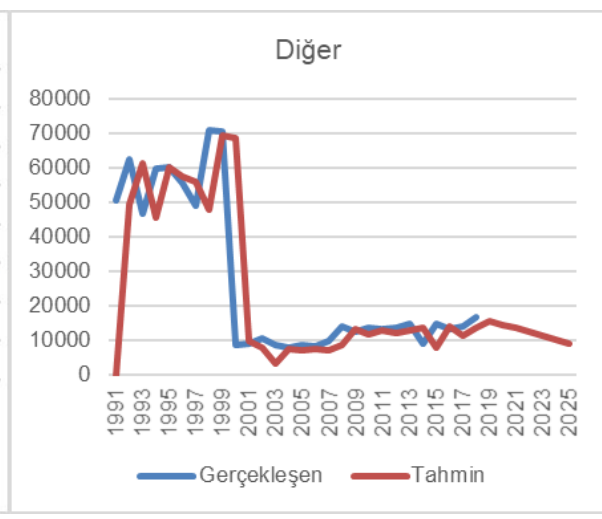

b)

Şekil 6. Bartın ve diğer illerin gerçekleşen ve tahmin edilen findık rekolteleri 
Fındıkta önde gelen illerin Türkiye üretimindeki payları

Türkiye'de 2018 yılı itibari ile 32 ilde findık üretimi yapılmış olup, findık üretiminde önde gelen iller Ordu, Sakarya, Samsun, Düzce, Giresun, Trabzon, Zonguldak, Kocaeli, Kastamonu, Artvin ve Bartın'dır (TÜİK, 2019). Çizelge 1'de Türkiye'nin findık üretimi yedi yıllık dönemler ortalamasına göre 1991-2018 (28 yll) ve 2019-2025* (7 ylllı) ARIMA modeliyle elde edilen tahmini üretimleri verilmiştir. Ayrıca Türkiye'de findık yetiştiriciliğinde önde olan on ilin, aynı dönemlerde Türkiye'nin üretiminde ne kadar paya sahip olduğu/olacağı aynı çizelgede hesaplanmıştır.

Çizelge 1. Fındık üretiminde önde gelen illerin türkiye üretimindeki payları (\%)

\begin{tabular}{|c|c|c|c|c|c|c|}
\hline İller & 1991-1997 & 1998-2004 & $2005-2011$ & $2012-2018$ & $2019-2025^{*}$ & ARIMA \\
\hline Ordu & 29.24 & 27.50 & 26.90 & 28.02 & 30.16 & 3.1 .1 \\
\hline Samsun & 8.62 & 9.17 & 13.21 & 14.12 & 16.35 & 1.1 .1 \\
\hline Sakarya & 14.14 & 19.71 & 15.55 & 15.45 & 15.22 & 1.1 .0 \\
\hline Giresun & 18.13 & 15.17 & 13.97 & 12.70 & 12.53 & 1.1 .1 \\
\hline Düzce & 0.00 & 8.94 & 12.27 & 11.50 & 11.03 & 0.1 .1 \\
\hline Trabzon & 11.35 & 9.15 & 7.84 & 7.11 & 6.51 & 3.1 .1 \\
\hline Zonguldak & 2.83 & 2.86 & 4.27 & 4.49 & 4.43 & 1.1 .1 \\
\hline Artvin & 0.94 & 0.78 & 1.41 & 1.39 & 1.05 & 0.1 .0 \\
\hline Kocaeli & 1.43 & 1.29 & 2.14 & 1.67 & 2.21 & 5.1 .3 \\
\hline Bartın & 0.25 & 0.31 & 0.47 & 1.08 & 0.50 & 4.1 .0 \\
\hline Diğerleri & 13.07 & 5.12 & 1.97 & 2.47 & 2.11 & 3.1 .0 \\
\hline Türkiye (1000 ton) & 420.14 & 519.29 & 578.83 & 558.97 & 589.04 & \\
\hline
\end{tabular}

Kaynak: TÜİK, 2019.

*ARIMA modelinden elde edilen tahmin sonuçları

Makro açıdan bakıldığında Türkiye'de findık üretimi 1991-1997 döneminde 420.140 ton iken dönemler içerisinde genelde bir artış göstererek 2019-2025 yılları arasında 589.040 tona ulaşılacağı tahmin edilmektedir. Mikro açıdan bakıldığında ise Ordu, Samsun ve Kocaeli illerinde bir önceki dönem temel alındığında fındık üretiminde gelecek 7 yılda oransal olarak bir artıș beklenirken, diğer illerde ise bir azalıș söz konusu olacaktır. Ayrıca en fazla üretimin yapıldığı 10 ilin toplamdaki payı \%98'lere kadar yükselecek diğer illerin payı ise giderek azalacaktır. Çizelgede dikkat çeken başka bir özellik ise Giresun ilinin giderek kan kaybediyor olmasıdır. 1991-1997 yılları ortalamasına göre Türkiye'deki üretim payı yaklaşık \%6 azalmıştır. Samsun ili ise bu dönemde en fazla üretim artışı gösterecek il olup, üretim artışı \%8 olarak gerçekleşecektir. Bu artış Samsun ilini 2. sıraya yükseltecek ve Sakarya ilinin 3. sıraya gerilemesine neden olacaktır. Uzundumlu ve Kurtoglu (2018), son yıllarda fındık makro açıdan incelendiğinde daha önce findık üretimi olmayan Gürcistan ve Azerbaycan'ın bu ürünün üretimini artırması ile bu ülkelerin dünya üretimindeki payının artması Türkiye'nin payını az da olsa azaltmaya başlamıștır. Benzer bir durum mikro açıdan bakıldığında 2000 yılından sonra üretime başlayan Düzce ilinde görülmektedir. Bu ilin payı giderek artmakta olup, bu il ile birlikte Samsun, Sakarya ve Bartın illerinin payını artırması Ordu ilinin payının herhangi bir değişime uğratmazken
Giresun ilinin payının giderek azalmasına neden olmuștur.

Çelik (2003), Türkiye'nin 2012-2018 yılları ortalama findık üretimini 1961-2011 yılı verilerini dikkate alarak ARIMA(0,1,1) modelini uygulayarak 605.165 ton olarak belirlemiştir. Buna göre gerçekleşen değer ile beklenen değer arasında \%8'lik bir sapma olmuştur. Ayrıca Bars ve ark., (2018), 1944-2017 yılları arası 74 yıllık verileri (ARIMA $(1,2,2)$ modelini kullanarak Türkiye'nin 2018 yılı findık üretiminin yaklaşık olarak 639.000 ton olarak tespit etmişlerdir. TÜİK (2019), verilerine göre 2018 yılındaki findık üretimi 515.000 ton olup sapma oranı \%24'tür. Ayrica Uzundumlu ve Kurtoglu (2018), yapmıș oldukları çalışmada 1961-2017 yıllarına ait 57 yıllık FAO verilerine ARIMA $(1,1,1)$ modelini uygulayarak 2018 yll tahminini 668 bin ton ve 2017-2025 yılı ortalamasını 706 bin ton olarak tahmin etmișlerdir. $\mathrm{Bu}$ sonuçlar dikkate alındığında Türkiye geneli yerine, önde gelen ve diğer illerin tahminleri toplamına göre Türkiye üretimini tahmin etme, gerçek değere yakın sonuçlar vermektedir. Bu nedenle bu çalışmadan elde edilen tahmin sonuçlarındaki sapmanın daha düşük olacağı beklenmektedir.

Çizelge 2'de Türkiye'nin fındık üretiminde önde gelen on ildeki yıllık ortalama meyve veren findık ağacı sayıları verilmiştir. 
Çizelge 2. Fındık üretiminde önde gelen illerin yıllık ortalama meyve veren ağaç sayısı (1.000 adet)

\begin{tabular}{ccccccc}
\hline İler & $\begin{array}{c}\text { A } \\
1991-1997\end{array}$ & $\begin{array}{c}\text { B } \\
1998-2004\end{array}$ & $\begin{array}{c}\mathrm{C} \\
2005-2011\end{array}$ & $\begin{array}{c}\mathrm{D} \\
2012-2018\end{array}$ & $\begin{array}{c}\text { D’nin C'ye } \\
\text { Göre \% Değişimi }\end{array}$ & $\begin{array}{c}\text { D'nin B'ye } \\
\text { Göre } \% \\
\text { Değișimi }\end{array}$ \\
\hline Ordu & 83285 & 97202 & 116243 & 123214 & 6.00 & 26.76 \\
Giresun & 56470 & 56683 & 63475 & 59855 & -5.70 & 5.60 \\
Sakarya & 28281 & 34142 & 34195 & 35575 & 4.04 & 4.20 \\
Samsun & 23304 & 30111 & 42452 & 44703 & 5.30 & 48.46 \\
Trabzon & 25856 & 22401 & 24213 & 29512 & 21.89 & 31.74 \\
Düzce & 0 & 19359 & 31205 & 31898 & 2.22 & 64.77 \\
Zonguldak & 8305 & 10351 & 16086 & 16011 & -0.46 & 54.69 \\
Kocaeli & 3911 & 4100 & 5015 & 2828 & -43.61 & -31.03 \\
Artvin & 2408 & 2356 & 3391 & 2429 & -28.37 & 3.10 \\
Bartın & 890 & 1168 & 1984 & 3722 & 87.62 & 218.72 \\
\hline Türkiye & 259031 & 291250 & 345143 & 357948 & 3.71 & 22.90 \\
\hline
\end{tabular}

Çizelgede 2'de görüldüğü üzere 1998-2004 ile 20122018 dönemi arasında yıllık ortalama meyve veren fındık ağacı sayısı Türkiye'de \%22.90 artmıştır. Aynı dönem içerisinde en fazla artış sağlayan iller Bartın $\% 218.72$, Düzce \%64.77, Zonguldak \%54.69, Samsun \%48.46 ve Trabzon \%31.74'tür. 2005-2011 ve 20122018 dönemi karşlaştırıldığında ise Türkiye'nin meyve veren ağaç sayısında \%3.71'lik bir artış olmuştur. Aynı dönem içerisinde en fazla artış sağlayan iller Bartın \%87.62, Trabzon \%21.89, Ordu \%6.00, Samsun \%5.30'dur. Aynı dönemde Kocaeli'nde \%43.61, Artvin'de \%28.37, Giresun'da $\% 5.70$ ve Zonguldak'ta \%0.46 azalma olmuștur. $\mathrm{Bu}$ azalmaların nedeni ZMO (2016)'da şu şekilde açıklanmıştır: Türkiye'de en uygun alanlarda fındık üretimi yapmak için ilk adım 1983 yılında atılmış olup, 1993 yılında fındık üretiminde bulunan ancak Bakanlar Kurulu kararınca belirlenmiş tüm alan dışındaki fındık bahçelerinin sökümü karşılığında tazminatlar düzenlenmiştir. Ancak kaynak sıkıntısı nedeniyle uygulanamamıştır. 2001 yılında fındık üretiminde iyi olmayan alanlarda fındık bahçelerinin alternatif ürüne dönüştürenlere destek verilmesi amaçlanmıştır. Burada da istenen başarı sağlanamamıștır. 2009 yılında ise fındık üretiminde önde gelen illerde 1 . sinıf ve 2 . sinıf arazilerin yanında eğimi \%6'nın altında olan findık bahçelerinin yeniden tesis edilmesi ve yenilenmesinin önüne geçilmiștir. 2014'te yalnızca 16 il ve bunlara bağlı 123 ilçede findık üretim izni çlkarılmıștır. Bu durumda fındık üretim alanları ile birlikte onun verim ve kalitesinin de (fiyatının da) çalışmada dikkate alınması gereken bir durum olduğu ortaya konmuştur.

\section{Findık üretiminde önde gelen illerin verim ve fiyat durumları}

Fındığın şekli onun verim ve kalitesi üzerinde önemli bir etkiye sahip olduğu bilinmektedir. Fındık şekilsel olarak yuvarlak (tombul), sivri ve uzun (badem) olmak üzere üç gruba ayrılmakta olup, en kalitelileri yuvarlak şekillilerdir. Yuvarlak olan grupta yer alan çeşitler Cavcava, Çakıldak, Foşa, Kalınkara, Kan, Karafındık, Kargalak, Mincane, Palaz, Tombul ve Uzunmusa'dır. Şekli sivri olan grup orta veya düşük kaliteli Acı, İncekara, Kuş ve Sivri gibi çeşitleri içermektedir. Şekilsel olarak uzun grubunda yer alan fındıklar yassı ve yuvarlak badem çeșitlerini içermekte olup kaliteleri düşüktür (Ceran Güraslan, 2018; Anonim, 2019a).

Türkiye'de findık kalitesi denince Giresun ve levant kalite fındık akla gelmektedir. Giresun kalite, dünyadaki en kaliteli en üstün özelliklere sahip içerdiği yağ oranı ve tadı ile dünyanın bir numarasıdır. $\mathrm{Bu}$ findık tombul bir findık olup Giresun, Ordu, Samsun ve Trabzon'un Beşikdüzü, Vakfikebir, Çarşıbaşı ve Akçaabat ilçelerinde yaygın bir şekilde yetiştirilmektedir. Levant kalite fındık ise Giresun findığına göre daha az yağ içermekte olup, Trabzon'da Cavcava, Foșa, Kargalak ve Mincane çeșitleri bu kalitedeki fındıklardır. Levant kalite findık Giresun'da Kalınkara ve Palaz, Ordu'da, Çakıldak, Kalınkara, Palaz ve Uzunmusa, Samsun'da Çakıldak ve Palaz, Düzce, Sakarya, Kocaeli, Zonguldak ve Bartın illerinde ise Çakılldak, Foşa, 
Karafındık, Mincane ve Palaz çeşitleri olarak geniş bir alanda yetiștirilmektedir (Anonim, 2019b; TMO,
2019). Çizelge 3'te Türkiye'nin fındık üretiminde önde gelen on ildeki fındık verimleri verilmiştir.

Çizelge 3. Fındık üretiminde önde gelen illerin alan ve ağaç verim değerleri

\begin{tabular}{|c|c|c|c|c|c|c|c|c|}
\hline \multirow{3}{*}{ İller } & \multicolumn{2}{|c|}{ 1991-1997 } & \multicolumn{2}{|c|}{ 1998-2004 } & \multirow{2}{*}{$\begin{array}{c}2005- \\
2011 \\
\text { Verim }\end{array}$} & \multicolumn{3}{|c|}{$2012-2018$} \\
\hline & \multicolumn{2}{|c|}{ Verim } & \multicolumn{2}{|c|}{ Verim } & & \multicolumn{3}{|c|}{ Verim } \\
\hline & $\mathrm{kg} / \mathrm{da}$ & kg/ağaç & $\mathrm{kg} / \mathrm{da}$ & kg/ağaç & $\mathrm{kg} / \mathrm{da}$ & kg/ağaç & $\mathrm{kg} / \mathrm{da}$ & $\mathrm{kg} / \mathrm{ağaç}$ \\
\hline Ordu & 73.01 & 1.43 & 79.91 & 1.43 & 73.04 & 1.29 & 68.96 & 1.33 \\
\hline Samsun & 122.58 & 1.71 & 116.72 & 1.43 & 90.48 & 2.00 & 83.74 & 2.00 \\
\hline Sakarya & 53.12 & 2.14 & 70.47 & 2.86 & 110.81 & 2.57 & 97.65 & 2.33 \\
\hline Giresun & 66.36 & 1.43 & 104.39 & 1.71 & 82.77 & 1.14 & 73.27 & 1.50 \\
\hline Düzce & 0.00 & 0.00 & 73.18 & 2.14 & 113.30 & 2.14 & 102.31 & 2.17 \\
\hline Trabzon & 95.17 & 2.14 & 95.13 & 1.71 & 82.15 & 1.71 & 60.85 & 1.33 \\
\hline Zonguldak & 80.65 & 1.29 & 80.61 & 1.86 & 104.24 & 1.71 & 106.04 & 1.67 \\
\hline Artvin & 92.36 & 1.57 & 101.45 & 1.43 & 69.47 & 2.00 & 85.38 & 2.00 \\
\hline Kocaeli & 92.90 & 1.57 & 92.74 & 1.71 & 143.14 & 2.57 & 116.05 & 3.50 \\
\hline Bartın & 54.04 & 1.00 & 61.09 & 1.86 & 172.54 & 1.29 & 105.29 & 2.00 \\
\hline Türkiye & 78.89 & 1.61 & 91.21 & 1.78 & 87.02 & 1.57 & 79.08 & 1.57 \\
\hline
\end{tabular}

Kaynak: TÜIK, 2019.

Dönemler içerisinde Türkiye'de hem alan hem de ağaç başına findık verimi incelendiğinde 1991-1997 döneminde Türkiye'de dekara verim $78.89 \mathrm{~kg}$ iken artış ve azalışlarla 2012-2018 döneminde 79.08 kg'a yükselmiş ve ağaç başına verim ise $1.61 \mathrm{~kg}$ 'dan 1.57 kg'a düșmüștür. 1998-2004 döneminde genelde alana ve ağaç başına verim artışı olmuş bunun nedeni eğimi \%6'nın altında olan arazilerde findık üretimi artışından kaynaklanmış olabilir. Bundan sonraki yapılan düzenlemelerden bu döneme göre sonraki dönemlerde verim biraz düșmüștür. Mikro açıdan iller bazında verime bakıldığında ise dekara verim 53-173 $\mathrm{kg}$ ve ağaç başına verim 1.00-3.50 kg arasında değerler almaktadır. İlk ve son dönemler karşılaştırıldığında sadece Ordu ve Trabzon hem alan hem de ağaç başına verimde düşüş yaşarken Samsun ili alan bakımından düşüş sağlarken, ağaç başına artış sağlamıştır. Diğer 7 il hem alan hem de ağaç başına düşen verimde artış sağlamışlardır. Verim artışında Fındık Araştırma Enstitüsü'nün yapmış olduğu illere göre çeşit denemeleri ve fındık bahçelerini gençleștirme projelerinin etkisi olabilir. Kızıltan ve Yalçın (2010)'a göre bazı bölgelerde aynı özelliklere sahip fındık bahçelerinde verimin daha yüksek olmasının nedeni bu bölgedeki findık bahçelerinin daha genç olmasından kaynaklanmaktadır. Fındık ağacının ekonomik ömrü 40 yıl olarak düşünülmekte bu nedenden dolayı ekonomik ömrünü bitiren bahçelerinin yerine yenilerinin dikilmesiyle verim artışı sağlanmaktadır.

Çizelge 4'te Türkiye'nin fındık üretiminde önde gelen on ildeki fındık fiyatları verilmiștir.

Türkiye'de findık fiyatları genellikle Ordu ve Giresun illerinin ortalamasındaki bir fark kadar değişmektedir. Türkiye'nin fındık fiyatı dönemler itibariyle 1.32 \$'dan 3.41 \$'a kadar yükselmiștir. 2012-2018 yıllarında ortalama findık satış fiyatı 1998-2004 ve 2005-2011 yıllarına göre değişimi \%126.31 ve \%19.49'dur. İllerin karşılaștırması yapıldığında bu dönemler içerisinde Ordu, Giresun ve Samsun tüm dönemler itibariyle en yüksek findık satış fiyatına sahip olan illerdir. Sakarya ili 19982004 döneminde sadece ilk beş il içerisine girememiştir. 1991-1997 ve 1998-2004 dönemlerinde Trabzon, 1998-2004 ve 2005-2011 dönemlerinde Artvin ve 2012-2018 döneminde ise Bartın fiyatı yüksek olan iller içerisinde kendine yer bulmuştur. Dönemler itibariyle fiyatlardaki artış oranlarına bakıldığında ise en fazla artışın olduğu iller sırasıyla Düzce, Bartın ve Kocaeli'dir. Yani bu illerde findık fiyatının yükselmesi bir nevi kalite artışını da göstermektedir. Tablodaki veriler dikkate alındığında Türkiye'de en kaliteli findıklar Giresun Ordu Samsun ve Sakarya illerinden elde edilmektedir. 
Çizelge 4. Fındık üretiminde önde gelen illerin dönemler itibari ile ortalama satış değerleri $(\$ / \mathrm{kg})$

\begin{tabular}{ccccccc}
\hline Iller & $\begin{array}{c}\mathrm{A} \\
1991-1997\end{array}$ & $\begin{array}{c}\mathrm{B} \\
1998-2004\end{array}$ & $\begin{array}{c}\mathrm{C} \\
2005-2011\end{array}$ & $\begin{array}{c}\mathrm{D} \\
2012-2018\end{array}$ & $\begin{array}{c}\text { D'nin C'ye } \\
\text { Göre \% Değişimi }\end{array}$ & $\begin{array}{c}\text { D'nin B'ye } \\
\text { Göre } \% \\
\text { Değişimi }\end{array}$ \\
\hline Ordu & 1.32 & 1.53 & 3.04 & 3.46 & 13.75 & 125.93 \\
Giresun & 1.33 & 1.58 & 3.06 & 3.67 & 19.71 & 132.57 \\
Sakarya & 1.37 & 1.45 & 2.89 & 3.37 & 16.45 & 132.86 \\
Samsun & 1.34 & 1.65 & 2.83 & 3.45 & 21.72 & 109.41 \\
Trabzon & 1.33 & 1.47 & 2.67 & 3.22 & 20.50 & 119.07 \\
Düzce & - & 1.13 & 2.38 & 3.31 & 39.15 & 192.55 \\
Zonguldak & 1.26 & 1.35 & 2.61 & 3.13 & 20.01 & 132.00 \\
Kocaeli & 1.22 & 1.22 & 2.42 & 3.18 & 31.36 & 160.47 \\
Artvin & 1.24 & 1.54 & 3.00 & 3.22 & 7.45 & 109.18 \\
Bartın & 1.25 & 1.30 & 2.43 & 3.42 & 40.84 & 163.47 \\
\hline Türkiye & 1.32 & 1.51 & 2.85 & 3.41 & 19.49 & 126.31 \\
\hline
\end{tabular}

Kaynak: Anonim, 2019c; TÜiK, 2019.

*Ürünlerin o yılkı ortalama fiyatları \$ cinsinden hesaplanmıștır.

\section{Sonuç ve Öneriler}

Ekonomik ve sosyal açıdan fındık Türkiye'de çok önemli bir yere sahiptir. Geçmişten bugüne Türkiye'nin birçok ilinde findık üretimi yapılmakta, ancak ekonomik değeri olmayan veya findık dışında başka alternatif ürünlerin üretilmesi mümkün olan bölgelerde findık yetiştirilmesi son 10 yılda büyük tartışmalara neden olmuştur. Fındık üretiminde hem kalite hem de mutlak veya mukayeseli üstünlük prensiplerinin dikkate alınması gerektiği bu tartıșmalarda ortaya konulmuștur. Ayrıca çok fazla alanda üretimin olması fındık fiyatlarını çok düşürmektedir. $\mathrm{Bu}$ durumda üreticiler büyük bir ekonomik kayba uğramaktadır. Özellikle üretimin 600.000 ton üzerinde gerçekleşmesi fiyat düşüşüne neden olmaktadır. Böylece Tarım ve Orman Bakanlığı 2004 yılından itibaren fındık üretiminde kalite bakımından önde olan ve dağlık alanlarda başka ürünlere göre avantajlı olan illerde fındık üretiminde ihtisaslaşmalarını amaçlamaktadır. Aynı yıl findık yetiştiren il sayısı Bakanlar Kurulu Kararıyla 16 ilde sınırlandırılmış ve 1 ve 2 . sınıf ile eğimi \%6'nın altındaki arazilerde yeniden fındık bahçesi düzenlenmesinin önüne geçilmiştir.

1991-1997 yılları ortalamasına göre 420.140 ton findık elde edilmiş olup, bu üretimin \%72.86'sı Ordu (\%29.24), Giresun (\%18.13), Sakarya (\%14.14) ve Trabzon (\%11.35) illerinden sağlanmıştır. 19982004 yılları ortalamasına göre ise 519.290 ton findık elde edilmiş olup bu üretimin \%71.55'i Ordu
(\%27.50), Sakarya (\%19.71), Giresun (\%15.17) ve Samsun (\%9.17) illerinden sağlanmıștır. 2005-2011 yılları ortalamasına göre ise 578.830 ton findık elde edilmiş olup bu üretimin \%69.63'ü Ordu (\%26.90), Sakarya (\%15.55), Giresun (\%13.97) ve Samsun (\%13.21) illerinden sağlanmıștır. 2012-2018 yılları ortalamasına göre ise 558.970 ton findık elde edilmiș olup bu üretimin \%70.29'u Ordu (\%28.02), Sakarya (\%15.45), Samsun (\%14.12) ve Giresun (\%12.70) illerinden sağlanmıştır. Ayrıca en iyi 10 il dışındaki diğer illerin üretimi ise ilk yıllarda \%13'lerden, \%5’lere ve son ylllarda \%2.00-2.50'lere düşmüştür. Yani Giresun ve Trabzon illerinin payı düşerken özellikle Samsun ve Sakarya illerinde artış göstermiştir. Böylece Sakarya ve Samsun illeri 2 ve 3 . sıraya yerleşmiştir. Son yıllarda üretimde büyük bir potansiyele (\%11-12) sahip olan Düzce ili ise siralamada 5. il olma yolundadır. ARIMA tahmin sonuçlarına göre 2019-2025 yılları ortalamasına göre 589.040 ton findık elde edilecektir. 2019-2025 yılları ortalamasına göre Ordu ili \%30.16 ile ilk sırada, Samsun \%16.35'le ikinci sırada, Sakarya \%15.22 ile 3. sirada, Giresun \%12.53'le 4. sirada, Düzce \%11.03 ile 5. sirada, Trabzon \%6.51 ile 6.sırada ve Zonguldak \%4.43 ile 7. sirada yer alacaktır. $\mathrm{Bu} 7$ il Türkiye findık üretiminin \%96.23'ünü oluşturacaktır.

Türkiye'nin yedişer yıllık dört dönem ortalamaları dikkate alındığında, 2012-2018 döneminde önceki 3 döneme göre meyve veren ağaç sayısında sırasıyla \%38.19, \%22.90 ve \%3.71'lik bir artış sağlanmıștır. 
En fazla artış sağlayan iller Bartın, Düzce, Samsun, Trabzon, Ordu ve Sakarya illeri iken en fazla düşüş Kocaeli, Artvin ve Giresun illerinde olmuştur.

Türkiye'deki 4 dönem dikkate alındığında en fazla verimin olduğu dönem 1998-2004 yılları olmuștur. $\mathrm{Bu}$ dönemde genel olarak tüm illerde verim artışı sağlanmış olup, Türkiye'de ağaç başına verim bir önceki döneme göre 1.61 kg'dan 1.78 kg'a ve dekara verimde 78.89 kg'dan 91.21 kg'a yükselmiștir. Bu dönemdeki yükselmenin en büyük nedeni birinci ve ikinci sınıf arazilerde findık yetiștirilmesi ve eğimi \%6'nın altında olan arazilerin findık üretimine tahsis edilmesidir. $\mathrm{Bu}$ dönemden sonra yapılan müdahaleler sonucunda verim sonraki dönemlerde biraz daha düşmüştür. Ağaç başına verim Türkiye'de 1.57 kilogram civarında olup, illere göre $1.33-3.5 \mathrm{~kg}$ arasında değişmektedir. Verim bakımından bazı illerin verimi düşük olmakta bu nedenden dolayı verimi düşük olan illerde Fındık Araştırma Enstitüsü yaş bahçelerini yenileyecek işletmelere, o bölgelerdeki kalite ve verim denemelerine göre bahçe tesis etmeleri ile verim artışı sağlanabilir.

Türkiye'de yıllar itibariyle \$ cinsinden fındık fiyat artmaktadır. Fiyatlar dikkate alındığında Türkiye'deki üretim 600.000 ton üzerinde olduğunda dünya findık piyasasındaki fiyatlar aşırı düşmektedir. $\mathrm{Bu}$ durumda Türkiye'nin Ekonomik kaybı çok büyük olmaktadır. Bu nedenle fındık üretiminde çok verimli bölgelerde findık dışında alternatif ürün yetişebilecek düz arazilerde başka ürünlerin yetiştirilmesi teşvik edilmektedir. Yani fındık kalitesi bakımından yüksek ve fiyat bakımından iyi olarak kabul gören bölgelerde fındık üretimi teşvik edilmekte diğer bölgelerde ise başka alternatif ürünlerin tahsis edilmesi amaçlanmaktadır. Yıllar itibariyle fındık fiyatları dikkate alındığında en fazla satış fiyatına sahip olan iller kalitede de önde olan Ordu, Giresun Samsun ve Sakarya illeridir. Son yıllarda Bartın ve Artvin illeri de bu gruba dâhil edilmiștir. Türkiye'nin 2019-2025 yıllarında 600.000 tonun altında üretime sahip olacak beklentisi nedeni ile findık fiyatlarının makul ölçüler doğrultusunda olacağı ve üreticilerin ekonomik kayba uğramayacağı beklenmektedir. Türkiye'nin fındık stokları da dikkate alınarak yıllık üretim tahminlerinin yapılarak yıllık maksimum üretim düzeylerini belirleyecek çalıșmalara ihtiyaç vardır. Geliștirilecek yıllık fındık üretim formülü ile Türkiye'nin ekonomik kazancı artırılabilir. İleride fındık üretim miktarı hakkında yapılacak diğer çalışmalar fındık üreticileri ve fındık sektöründe çalışma yapan araştırmalara yol gösterici nitelikte olabilir.

\section{Kaynaklar}

Anil, S., Kurt, H., Akar, A., Bulam, Kose, C., 2018. Hazelnut culture in Turkey. XXX. International Horticultural Congress. (12-16 August, Istanbul), (Web page: http://www.ihc2018.org/files/downloads/ch5604 Hazelnut-HR.pdf) (Date accessed: April08, 2019).

Anonim, 2019a. Türkiye'de Yetiştirilen Önemli Fındık Çeșitleri. Fındık Tarım Satıș Kooperatifleri Birliği (FISKOBIRLIK) Giresun Dereli Kooperatifi, (Web sayfası: http://Dereli.Fiskobirlik.Org.Tr/Duyurular.Php? Id=3) (Erişim Tarihi: 11.05.2019).

Anonim, 2019b. Tarım ve Orman Bakanlığı Fındık Araștırma Enstitüsü Müdürlüğü (Web sayfası: https://arastirma.tarimorman.gov.tr/findik) (Erişim Tarihi: 07.06.2019).

Anonim, 2019c. 1991-2018 Yılları TL/Dolar Kur Hesaplamaları (Web sayfası: http://paracevirici.com/doviz-arsiv/merkez-bankasi/gecmistarihli-doviz/2015/amerikan-dolari (Erişim Tarihi: 07.06.2019).

Atsan, T., Karapınar, A., 2019. Türkiye fındık ihracatını etkileyen faktörler: Çekim modeli uygulaması. Akademik Sosyal Araștırmalar Dergisi, 7 (89): 430 444.

Bars, T., Uçum, I., Akbay, C., 2018. ARIMA modeli ile Türkiye findık üretim projeksiyonu. Kahramanmaraș Sütçü İmam Üniversitesi Tarım ve Doğa Dergisi, 21; 154-160.

Box, G.E., Jenkins, G.M., Reinsel, G.C., Ljung, G.M., 2016. Time Series Analysis: Forecasting and Control. $5^{\text {th }}$ Edition, John Wiley and Sons Inc. Hoboken, New Jersey, USA.

Çelik, Ş., 2013. Sert kabuklu meyvelerin üretim miktarının Box-Jenkins tekniği ile modellenmesi. Yüzüncü Yıl Üniversitesi Tarım Bilimleri Dergisi, 23 (1): 18-30.

Ceran Güraslan, D., 2018. Türkiye'de Üretilen Farklı Fındık Çeşitlerinin Fındık Zarı ve Fındık Küspesinin Bileşimi, Fenolik Madde Miktarı ve Antioksidan Aktivitelerinin Belirlenmesi, Mersin Üniversitesi, Fen Bilimleri Enstitüsü, Yüksek lisans tezi, Mersin, $45 \mathrm{~s}$.

Eryılmaz, G.A., Kılıç, O., 2019. Türkiye'nin organik fındık üretimi ve ihracatındaki gelişmeler. Fırat Üniversitesi İ̈BF Uluslararası İktisadi ve İdari Bilimler Dergisi, 3 (1): 41-54.

FAOSTAT, 2019. Food and Agriculture Organization of the United Nations. (Web page: http://www.fao.org 
/faostat/en/\#data/QC (Date accessed: March01, 2019).

Fideghelli, C., De Salvador, F.R., 2009. World Hazelnut situation and perspectives. Acta Horticulturae, 845: 39-52.

Hasmida, H., 2009. Water Quality Trend at the Upper Part of Johor River in Relation to Rainfall and Runoff Pattern., Faculty of Civil Engineering, University Technology, MS Thesis, Malaysia, 66 s.

ITC, 2019. Produce and Trade of Hazelnuts. (Web page: https://www.trademap.org/Country_SelProductCo untry_TS.aspx?nvpm $=1 \% 7 \mathrm{c} 792 \% 7 \mathrm{c} \% 7 \mathrm{c} \% 7 \mathrm{c} \% 7 \mathrm{c} 0$ 80222\%7c\%7c\%7c6\%7c1\%7c1\%7c2\%7c2\%7c1 \%7c2\%7c1\%7c) (Date accessed: April19, 2019).

İpek, N.K., 2019. Aralıklı Talep Tahmin Modellemesi. Başkent Üniversitesi Fen Bilimleri Enstitüsü, Yüksek lisans tezi, Ankara, 76 s.

Kilic, O., Alkan, I., 2006. The developments in the world hazelnut production and export, the role of Turkey. Journal of Applied Sciences, 6 (7): 1612-1616.

Kızıltan, A., Yalçın, H. 2010. Türkiye'de fındık sektöründe üreticilerin sorunları: Samsun ilinde bir uygulama. Atatürk Üniversitesi İktisadi ve İdari Bilimler Dergisi, 24 (4): 79-98.

Kohvakka, S., 2017. Forecasting Univariate Time SeriesComparison of Statistical Methods and Software Resources Available to Undergraduate Students. LUT School of Business and Management, MS Thesis, Finland, $47 \mathrm{~s}$.

Kurtoğlu, S., 2018. Türkiye'nin 2018-2025 Dönemindeki Yumurta Üretiminin ARIMA Modeliyle Tahmini. Atatürk Üniversitesi Fen Bilimleri Enstitüsü, Yüksek lisans tezi, Erzurum, $181 \mathrm{~s}$.

Nath, B., Dhakre, D.S., Bhattacharya, D., 2019. Forecasting wheat production in India: An ARIMA modelling approach. Journal of Pharmacognosy and Phytochemistry, 8 (1): 2158-2165.

SAS, 2014. SAS 13.2 User's Guide The ARIMA Procedure. SAS Institute Inc., Cary, NC, USA. (Web page: https://support.sas.com/documentation/onlinedo c/ets/132/ARIMA.pdf) (Date accessed: May15, 2019).

Şahin, S., 2016. Türkiye'nin 1982:01-2015:02 dönemi ticaret bilançosu ve gayri safi (brüt) değişim diş ticaret hadleri ilişkisi. Yalova Üniversitesi Uluslararası Ticaret, Finans ve Lojistik Dergisi, 1 (1): 23-36.

TMO, 2019. Şubelere Göre Fındık Çeşitleri ve Mahalli Adlarl (Web sayfası: http://www.tmo.gov.tr /Main.aspx?ID=198) (Erișim Tarihi: 07.06.2019).

Tombesi, A., 2005. World Hazelnut Situation: Italy. Acta Horticulturae, 686: 649-657.

TÜİK, 2019. Türkiye İstatistik Kurumu Bitkisel Ürün İstatistikleri. (Web sayfası: http://tuikapp.tuik.gov.tr/bitkiselapp/bitkisel.zul) (Erişim Tarihi: 01.03.2019).

Uzundumlu A.S., Kurtoglu S., 2018. The role of Turkey in the world hazelnut production and exporting. International Conference on Food, Agriculture and Animal Sciences (ICOFAAS 2018), Antalya, Turkey.

Yaltirik, F., Efe, A., 2000. Dendrology Handbook, Gymnospermae-Angiospermea. Faculty of Forestry Publication, University of Istanbul Publication, Istanbul, Turkey.

Yıldırım, H., Alkan, B., 2018. Türkiye için bir makroekonomik belirsizlik endeksi önerisi. Bankacılar Dergisi, 104, 6-25.

ZMO, 2016. 2016 Yılı Ziraat Odası Tarafından Hazırlanan Findik Raporu. (Web sayfası: http://www.zmo.org.tr/genel/bizden_detay.php?k od=30070\&tipi=17\&sube $=0$ ) (Erişim Tarihi: 09.05.2019).

ZMO, 2018. 2018 Yılı Ziraat Odası Tarafından Hazırlanan Findık Raporu. (Web sayfası: http://www.zmo. org.tr/genel/bizden_detay.php?kod=30070\&tipi=1 7\&sube=0) (Erişim Tarihi: 24.04.2019). 